\title{
ARTICLES
}

\section{UNCITRAL Instruments on Enforcement of International Commercial Settlement Agreements Resulting from Mediation}

\author{
Herman Verbist
}

\section{Introduction}

UNCITRAL published several instruments in the fields of arbitration and mediation. The 1958 Convention on the Recognition and Enforcement of Foreign Arbitral Awards, also known as the New York Convention, is a key instrument in international arbitration. In 2014, the UNCITRAL Commission mandated the Working Group II 'Dispute Settlement' to prepare instruments on the enforcement of international commercial settlement agreements resulting from mediation. The Working Group II has prepared two instruments, a new Convention on the Enforcement of International Commercial Agreements resulting from Mediation (inspired by the New York Convention in the field of arbitration); and an amendment to the 2002 Model Law on International Commercial Conciliation. The amended Model Law and the draft Convention were adopted by consensus at the 51st session of the Commission of UNCITRAL on 25 June 2018. The General Assembly of the United Nations adopted the Convention at the 73rd Session on 20 December 2018. Both instruments will provide common legislative standards for the enforcement of international commercial settlement agreements resulting from mediation and make such type of dispute settlement more efficient.

\section{Initiatives of UNCITRAL in the field of arbitration and conciliation}

UNCITRAL (United Nations Commission for International Trade Law) issued the Convention on the Recognition and Enforcement of Foreign Arbitral Awards ('the New York Convention') in 1958. This Convention seeks to provide common legislative standards for the recognition of arbitration agreements and court recognition and enforcement of foreign arbitral awards. In 2016, UNCITRAL published the UNCITRAL Secretariat Guide on the Convention on the Recognition and Enforcement of Foreign Arbitral Awards. The Guide analyses how the Convention is interpreted and applied by national courts, and promotes the uniform and effective interpretation and application of the Convention. As part of the preparation of the Guide, the website http://newyorkconvention1958.org/was 
launched in 2012. A new version of the website was launched in 2016 and provides free access to more than 1,200 cases. $^{1}$

UNCITRAL also issued the UNCITRAL Arbitration Rules in 1976. These rules cover most aspects of the arbitral process, from the contents of the arbitration clause to the effect and interpretation of the award, and are especially useful for the administration of ad hoc arbitrations. In order to meet the evolution of the arbitration practice, the UNCITRAL Arbitration Rules have been revised in 2010 and 2013. The UNCITRAL Commission published, in 2012, Recommendations to assist arbitral institutions and other interested bodies with regard to arbitration under the UNCITRAL Arbitration Rules, to inform and assist arbitral institutions and other interested bodies that might use the UNCITRAL Arbitration Rules as revised in 2010. The Arbitration Rules were adapted in 2013 in order to incorporate the UNCITRAL Rules on Transparency for arbitrations initiated pursuant to an investment treaty concluded on or after 1 April 2014.

UNCITRAL also adopted the Model Law on International Commercial Arbitration in 1985 to assist States in modernizing their arbitration laws. This Model Law is the result of an international consensus on main elements of practice and procedure of international arbitration, and was amended in $2006 .^{2}$

In 1996, the Commission issued the UNCITRAL Notes on Organising Arbitral Proceedings. These Notes aim to assist arbitration practitioners by providing a list of matters on which an arbitral tribunal may make decisions, if the parties agree, such as the place and language of an arbitration, and were up-dated in 2016.

In 2014, UNCITRAL issued the UNCITRAL Rules on Transparency in Treatybased Investor-State Arbitration. These rules, effective as of 1 April 2014, apply in relation to disputes arising out of treaties concluded prior to 1 April 2014, when Parties to the relevant treaty, or disputing parties, agree to their application; and to disputes arising out of treaties concluded on or after 1 April 2014, when Investor-State arbitration is initiated under the UNCITRAL Arbitration Rules, unless the parties otherwise agree. The Rules may apply in Investor-State arbitrations initiated under rules other than the UNCITRAL Arbitration Rules, and in ad hoc proceedings.

Also in 2014, UNCITRAL issued the United Nations Convention on Transparency in Treaty-based Investor-State Arbitration (the 'Mauritius Convention on Transparency'), by which parties to investment treaties concluded before 1 April 2014 express their consent to apply the UNCITRAL Rules on Transparency. ${ }^{3}$

1 http://newyorkconvention1958.org.

2 As of 1 January 2018, legislation based on the UNCITRAL Model Law has been adopted in 78 States in a total of 109 jurisdictions.

3 The Convention entered into force on 18 October 2017, following the ratification by three signatory States. 
In 1980, UNCITRAL adopted the UNCITRAL Conciliation Rules, which provide a set of procedural rules that cover most aspects of the conciliation process. To encourage the use of conciliation, UNCITRAL also adopted the Model Law on International Commercial Conciliation in 2002, which provides uniform conciliation rules. ${ }^{4}$ However, the 2002 Model Law does not contain provisions on enforcement of agreements resulting from conciliation (henceforth referred to as mediation).

\section{UNCITRAL instruments for the enforcement of international commercial settlement agreements resulting from mediation ${ }^{5}$}

At its 47th session, in 2014, the Commission of UNCITRAL agreed that Working Group II: Arbitration and Conciliation / Dispute Settlement ${ }^{6}$ (WGII) should consider the issue of enforcement of international settlement agreements resulting from conciliation (mediation) proceedings. ${ }^{7}$ At its 48th session, in 2015, the Commission agreed that WGII should commence the possible preparation of a convention, model provisions or 'guidance texts' on the topic. ${ }^{8}$

Since its 62nd session in February 2015 in New York, WGII has dedicated several sessions to the topic. During these sessions, consensus has been reached on important aspects: the scope of application of the instruments, the type of instruments, the terminology and the grounds for refusing to grant relief.

At the 63rd session of WGII in Vienna, in September 2015, there was a consensus that the scope of the instrument should be limited to the enforcement of 'commercial' settlement agreements. ${ }^{9}$ As a consequence, the proposed draft excluded personal, family, inheritance and employment matters from the scope of the instruments, as well as settlement agreements that would otherwise be enforceable as a judgment or as an arbitral award. ${ }^{10}$ There was also a consensus that it would not be desirable to exclude settlement agreements involving government

4 As of 1 January 2018, legislation based on the UNCITRAL Model Law has been adopted in 16 States in a total of 28 jurisdictions.

5 The new instruments were adopted at the 51st session of the UNCITRAL Commission on 25 June-13 July 2018 in New York; UNCITRAL Commission Report, 51st session, 25 June-13 July 2018, New York, A/73/17, paras. 49 and 68.

6 Working Group II of UNCITRAL: until the beginning of 2016, Working Group II was named 'Arbitration and Conciliation'; since late 2016, the name has been changed to 'Dispute Settlement'.

7 UNCITRAL Commission Report, 47th session, 7-18 July 2014, New York, A/69/17, para. 123.

8 UNCITRAL Commission Report, 48th session, 29 June-16 July 2015, Vienna, A/70/17, para. 142.

9 Report of Working Group II (Dispute Settlement) on the work of its 63rd session (Vienna, 7-11 September 2015), A/CN.9/861, para. 40.

10 Article 1 of the draft Convention on the Scope of application, see document A/CN.9/942. 
entities because some of these entities are engaged in commercial activities and might seek to use mediation to resolve disputes in the context of those activities. ${ }^{11}$

At its 65th session, in September 2016 in Vienna, WGII confirmed that settlement agreements involving States and other public entities should not be automatically excluded from the scope of the instrument. ${ }^{12}$

At its 66th session, in February 2017 in New York, a consensus was reached that WGII would further proceed, at the same time, with the elaboration of an additional provision for the UNCITRAL Model Law on Conciliation as well as the drafting of a Convention on the Enforcement of International Commercial Settlement Agreements Resulting from Mediation. ${ }^{13}$ In that regard, it was also agreed to suggest to the General Assembly of the United Nations, when adopting a resolution for the approval of these instruments, not to express a preference as to which of the two instruments should be adopted by the Member States. ${ }^{14}$

At its 67th session, in October 2017 in Vienna, there was a consensus that the instruments should refer to 'mediation' instead of 'conciliation', as 'mediation' is a more widely used term. ${ }^{15}$ The then proposed amended Model Law added a footnote to define mediation as 'a process where parties request a third person or persons to assist them in their attempt to reach an amicable settlement of their dispute arising out of, or relating to, a contractual or other legal relationship'. ${ }^{16}$

At its 68th session, in February 2018 in New York, WGII discussed and decided on the grounds for refusing to enforce or to invoke the settlement agreement in Article 5 of the then draft Convention and Article 18 of the amended draft Model Law. ${ }^{17}$ The Working Group confirmed that the grounds listed for refusing to grant relief in those provisions applied both to requests for enforcement and to situations where a party invoked a settlement agreement as a defence against a claim. ${ }^{18}$

11 Report of Working Group II (Dispute Settlement) on the work of its 63rd session (Vienna, 7-11 September 2015), A/CN.9/861, para. 46.

12 Report of Working Group II (Dispute Settlement) on the work of its 65th session (Vienna, 12-23 September 2016), A/CN.9/896, para. 62.

13 Report of Working Group II (Dispute Settlement) on the work of its 66th session (New York, 6-10 February 2017), A/CN.9/901, para. 93.

14 Ibid.

15 Report of Working Group II (Dispute Settlement) on the work of its 67th session (Vienna, 2-6 October 2017), A/CN.9/929, para. 104. It has been proposed that this change of terminology should also apply to the UNCITRAL Conciliation Rules (1980), A/CN.9/WG.II/WP.205, para. 4 (23 November 2017) (WGII 68th session, 5-9 February 2018).

16 A/CN.9/WG.II/WP.205, para. 5 (23 November 2017) (WGII 68th session, 5-9 February 2018); footnote 3 in document A/CN.9/WG.II/WP.205/Add.1 (23 November 2017) (WG II 68th session, 5-9 February 2018).

17 A/CN.9/WG.II/WP.205, para. 21 (23 November 2017) (WGII 68th session, 5-9 February 2018).

18 Report of Working Group II (Dispute Settlement) on the work of its 68th session (New York, 5-9 February 2018), A/CN.9/934, para. 41. 
The Working Group expressed a shared understanding that there might be overlap among the grounds provided for in paragraph 1 of Article 5 of the draft Convention and in paragraph 1 of Article 18 of the amended draft Model Law, and that competent authorities should take that aspect into account when interpreting the various grounds. ${ }^{19}$

With respect to a question whether the draft instruments should set forth how a competent authority would ascertain whether a settlement agreement falls within the scope of the exclusions of the instruments, it was noted that such a procedure would largely depend on the domestic rules of procedure and, therefore, it was not necessary for the draft instruments to prescribe any particular procedure for that purpose. ${ }^{20}$

\section{Convention on International Settlement Agreements Resulting from Mediation}

On 25 June 2018, the Commission of UNCITRAL adopted the draft Convention which is entitled 'United Nations Convention on International Settlement Agreements Resulting from Mediation'.21 The Commission has thereupon submitted this draft Convention for final adoption to the General Assembly of the United Nations at its 73rd session which was opened on 18 September 2018.

The Convention provides a preamble and 16 articles. It is structured as follows: ${ }^{22}$

Preamble

Article 1. Scope of Application

Article 2. Definitions

Article 3. General principles

Article 4. Requirements for reliance on settlement agreements

Article 5. Grounds for refusing to grant relief

Article 6. Parallel applications or claims

Article 7. Other laws or treaties

Article 8. Reservations

Article 9. Effect on settlement agreements

Article 10. Depositary

Article 11. Signature, ratification, acceptance, approval, accession

Article 12. Participation by regional economic integration organizations

Article 13. Non-unified legal systems

Article 14. Entry into force

19 Ibid., para. 65

20 Ibid., para. 24.

21 Report of the United Nations Commission on International Trade Law (UNCITRAL Commission 51st session, New York, 25-13 July 2018), A/73/17, para. 49.

22 Convention on International Settlement Agreements Resulting from Mediation, Report of the United Nations Commission on International Trade Law (UNCITRAL Commission 51st session, New York, 25-13 July 2018), A/73/17, paras. 50-55. 


\section{Article 15. Amendment}

Article 16. Denunciations

One of the key issues is how to prove that the settlement agreement was reached through mediation. ${ }^{23}$ Article 4(1)(b) of the Convention provides a list of means to evidence that the settlement agreement resulted from mediation. The understanding of the WGII is that only if the evidences mentioned could not be produced, then would the requesting party be allowed to submit any other evidence. ${ }^{24}$

Article 2 of the Convention contains definitions on 'the pace of business', a settlement agreement 'in writing' and 'mediation'. Mediation is defined as 'a process, irrespective of the expression used on the basis of which the process is carried out, whereby parties attempt to reach an amicable settlement of their dispute with the assistance of a third person or persons ("the mediator") lacking the authority to impose a solution upon the parties to the dispute'.

Article 3 provides that each Party to the Convention shall enforce a settlement agreement in accordance with its rules of procedure and under the conditions laid down in the Convention. If a dispute arises concerning a matter that a party claims was already resolved by a settlement agreement, a Party to the Convention shall allow the party to invoke the settlement agreement in accordance with its rules of procedure and under the conditions laid down in the Convention, in order to prove that the matter has already been resolved. The rules of procedure may thus differ in the States adhering to the Convention.

The title of Article 4 was after the discussion in WGII at its 68th session, in February 2018, changed from 'Application' to 'Requirements for reliance on settlement agreements' in order to better capture its content. ${ }^{25}$ Article 4 reflects a balance between the formalities that are required to ascertain that a settlement agreement resulted from mediation and the need for the Convention to preserve the flexible nature of the mediation process. ${ }^{26}$

Article 5 of the Convention lists the grounds for refusing to grant relief. It is to some extent mirrored on Article $\mathrm{V}$ of the Convention on the Recognition and Enforcement of Foreign Arbitral Awards (New York Convention). Article 5(1) lists the grounds which a party against whom enforcement of a settlement agreement is sought must prove, whilst Article 5(2) lists the grounds which a Court may raise at its own initiative in order to refuse enforcement of the settlement agreement.

23 Report of Working Group II (Dispute Settlement) on the work of its 67th session (Vienna, 2-6 October 2017), A/CN.9/929, paras. 52-59.

24 Report of Working Group II (Dispute Settlement) on the work of its 68th session (New York, 5-9 February 2018), A/CN.9/934, para. 38.

25 Settlement of commercial disputes - International commercial mediation: preparation of instruments on enforcement of international commercial settlement agreements resulting from mediation, A/CN.9/WG.II/WP.205/Add. 1 (23 November 2017) (68th session, 5-9 February 2018); ibid., para. 35 .

26 Report of the United Nations Commission on International Trade Law (UNCITRAL Commission 51st session, New York, 25-13 July 2018), A/73/17, para. 28. 
Article 6 provides the competent authority with the discretion to adjourn its decision if an application or claim relating to a settlement agreement has been made to a court, arbitral tribunal or other competent authority, which might affect the process. It is the understanding of the Working Group and of the Commission that Article 6 should apply both when enforcement of a settlement agreement is sought and when a settlement agreement is invoked as a defence. ${ }^{27}$

Article 7 mirrors Article VII of the New York Convention and aims at permitting the application of more favourable national legislation or treaties to matters covered by the Convention. It is the understanding of the Commission that (a) Article 7 should not allow States to apply the Convention to settlement agreements excluded under Article 1, paragraphs 2 and 3, as such settlement agreements fall outside the scope of the Convention, and (b) States nevertheless have the flexibility to enact relevant domestic legislation, which can include in its scope such settlement agreements. ${ }^{28}$

Article 8 provides the possibility for States to make reservations when signing the Convention. This allows States to declare that the Convention shall not apply to settlement agreements to which they are themselves or to which state agencies are a party (Article $8(1)(a)$ ). States may also make the reservation that the Convention shall only operate on an opt-in basis, if parties to a settlement agreement have agreed to the application of the Convention (Article 8(1)(b)). ${ }^{29}$

After the discussion in WGII at its 68th session, in February 2018 in New York, a new Article 9 entitled 'Effect on settlement agreements' was added. This provision clarifies that the Convention and any reservation or withdrawal thereof shall apply only to settlement agreements concluded after the date when the Convention, reservation or withdrawal thereof enters into force for the Party to the Convention concerned. ${ }^{30}$

Article 12 provides the possibility for a regional economic integration organization that is constituted by sovereign States and has competence over matters governed by the Convention to sign, ratify, accept, approve or accede to the Convention. This provision is included in the Convention as it is expected to facilitate a regional economic integration organization and its Member States becoming a Party to the Convention. ${ }^{31}$ Article $12(4)(b)$ ensures that when a party invoking a settlement agreement in a court of a Member State of the regional economic integration organization is not granted relief under the Convention, such a judgment by the Court will circulate within the regional economic integration organization, while that party will no longer be able to rely on the settlement agreement in a

31 Report of Working Group II (Dispute Settlement) on the work of its 68th session (New York, 5-9 February 2018), A/CN.9/934, para. 95. 
court of another Member State of the regional economic integration organization. $^{32}$

Article 13 dealing with non-unified legal systems permits a Contracting State to declare that the Convention extends to all its territorial units or only to one or more of them and to amend its declaration by submitting another declaration at any time. ${ }^{33}$

Pursuant to Article 14 of the Convention, 'the Convention shall enter into force six months after deposit of the third instrument of ratification, acceptance, approval, or accession'. The Working Group agreed that the Convention should provide that amendments would enter into force only for States that had expressed their consent to be bound by them, and that this would be the case for States adopting the Convention after the amendment. ${ }^{34}$

The General Assembly of the United Nations adopted the Convention on 20 December 2018 and declared the Convention open for signature by all States in Singapore on 7 August 2019, and thereafter at United Nations Headquarters in New York. ${ }^{35}$ The Convention shall be referred to as the 'Singapore Convention on Mediation'. ${ }^{36}$ Pursuant to Article 14, the Convention shall enter into force six months after deposit of the third instrument of ratification, acceptance, approval or accession.

\section{Amendment to the 2002 UNCITRAL Model Law on International Commercial Conciliation}

Also on 25 June 2018, the Commission of UNCITRAL adopted the amendments to the UNCITRAL Model Law on International Commercial Conciliation which is henceforth entitled 'UNCITRAL Model Law on International Commercial Mediation and International Settlement Agreements Resulting from Mediation, 2018'. ${ }^{37}$ Whereas the 2002 Model Law contained 14 articles, the amended 2018 Model Law contains 20 articles. It is structured as follows: ${ }^{38}$

32 Ibid., para. 97.

33 Report of Working Group II (Dispute Settlement) on the work of its 68th session (New York, 5-9 February 2018), A/CN.9/934, para. 99.

34 Ibid., para. 114.

35 Report of the United Nations Commission on International Trade Law (UNCITRAL Commission 51st session, New York, 25-13 July 2018), A/73/17, para. 44.

36 United Nations General Assembly Resolution A/Res/73/199, 20 December 2018.

37 Ibid., para. 68.

38 UNCITRAL Model Law on International Commercial Mediation and International Settlement Agreements Resulting from Mediation, 2018, Report of the United Nations Commission on International Trade Law (UNCITRAL Commission 51st session, New York, 25-13 July 2018), A/ 73/17, paras. $56-62$. 


\section{Section I - General Provisions}

Article 1. Scope of Application of the Law and definitions [new provision] Article 2. Interpretation [previously Article 2]

\section{Section II - International Commercial Mediation}

Article 3. Scope of Application of the section and definitions [previously Article 1]

Article 4. Variation by agreement [previously Article 3]

Article 5. Commencement of mediation proceedings [previously Article 4]

Article 6. Number and appointment of mediators [previously Article 5]

Article 7. Conduct of mediation [previously Article 6]

Article 8. Communication between mediator and parties [previously Article 7]

Article 9. Disclosure of information [previously Article 8]

Article 10. Confidentiality [previously Article 9]

Article 11. Admissibility of evidence in other proceedings [previously Article 10]

Article 12. Termination of mediation proceedings [previously Article 11]

Article 13. Mediator acting as arbitrator [previously Article 12]

Article 14. Resort to arbitral or judicial proceedings [previously Article 13]

Article 15. Binding and enforceable nature of settlement agreements [previously Article 14]

\section{Section III - International Settlement Agreements}

Article 16. Scope of Application of the section and definitions [new provision] Article 17. General principles [new provision]

Article 18. Requirements for reliance on settlement agreements [new provision]

Article 19. Grounds for refusing to grant relief [new provision]

Article 20. Parallel applications or claims [new provision]

When it adopted the draft amended Model Law and agreed to replace the word 'Conciliation' by 'Mediation' in the text of the Model Law, the Commission stressed that such modification should not have any implication as to the applicability of the Model Law to various fields where mediation is used, including Investor-State dispute settlement. ${ }^{39}$

It has been a guiding principle of WGII in its deliberations on the draft amended Model Law to ensure a level of consistency with the then draft Convention and, at the same time, to preserve the existing text of the Model Law to the extent possible. ${ }^{40}$ 
Section III with the Articles 16 to 20 is added to the text of the 2002 Model Law so as to address international settlement agreements in a manner consistent with the Convention. ${ }^{41}$

Article 16 of the 2018 Model Law corresponds essentially to Article 1 of the Convention.

Article 17 of the 2018 Model Law corresponds essentially to Article 3 of the Convention.

Article 18 of the 2018 Model Law contains the text of Article 4 of the Convention.

Article 19 of the 2018 Model Law contains the text of Article 5 of the Convention.

Article 20 of the 2018 Model Law corresponds essentially to Article 6 of the Convention.

The text of the 2018 Model Law also contains 7 footnotes, which contain suggestions and recommendations for the States wishing to adopt the Model Law. In a first footnote it is explained that the term 'commercial' in Article 1(1) should be given a wide interpretation so as to cover matters arising from all relationships of a commercial nature, whether contractual or not. In a footnote to Article 5 (Commencement of mediation proceedings) a text is suggested for States that may wish to adopt a provision on the limitation period. In a footnote to Section 3 (International Settlement Agreements - Articles 16 to 20), it is explained that a State may consider enacting this section to apply to agreements settling a dispute, irrespective of whether they resulted from mediation. It is stressed that in such case adjustments should then have to be made to relevant articles. In another footnote relating to Section 3, it is set forth that a State may consider enacting this section to apply only where the parties to the settlement agreement agreed to its application. Finally, in a footnote to Article 16(4), it is highlighted that a State may consider broadening the definition of 'international settlement agreement' by adding thereto that a settlement agreement is also international if it results from international mediation as defined in Article 3, paragraphs 2, 3 and 4 .

\section{Conclusion}

After four years of preparation, UNCITRAL adopted two instruments which will provide for common legislative standards for the enforcement of international commercial settlement agreements resulting from mediation and make such type of dispute settlement more efficient: a Convention on International Settlement Agreements Resulting from Mediation and the UNCITRAL Model Law on International Commercial Mediation and International Settlement Agreements Resulting 
from Mediation, 2018. The Commission adopted both instruments without creating any expectation that interested States may adopt either instrument. ${ }^{42}$

The Commission of UNCITRAL asked the Secretariat to compile the travaux préparatoires of the draft amended Model Law so that they can be easily accessible and also supplement the 'Guide to Enactment and Use of the UNCITRAL Model Law on International Commercial Mediation' and to provide guidance on how Sections 2 and 3 of the amended Model Law should each be enacted as a standalone legislative text. ${ }^{43}$

42 Report of Working Group II (Dispute Settlement) on the work of its 68th session (New York, 5-9 February 2018), A/CN.9/934, paras. 140-142.

43 UNCITRAL Commission Report, 51st session, 25 June-13 July 2018, New York, A/73/17, para. 67. 


\section{Annex I}

\section{United Nations Convention on International Settlement Agreements Resulting from Mediation}

\section{Preamble}

\section{The Paries to this Convention,}

Recognizing the value for international trade of mediation as a method for settling commercial disputes in which the parties in dispute request a third person or persons to assist them in their attempt to settle the dispute amicably,

Noting that mediation is increasingly used in international and domestic commercial practice as an alternative to litigation,

Considering that the use of mediation results in significant benefits, such as reducing the instances where a dispute leads to the termination of a commercial relationship, facilitating the administration of international transactions by commercial parties and producing savings in the administration of justice by States,

Convinced that the establishment of a framework for international settlement agreements resulting from mediation that is acceptable to States with different legal, social and economic systems would contribute to the development of harmonious international economic relations,

Have agreed as follows:

\section{Article 1. Scope of application}

1. This Convention applies to an agreement resulting from mediation and concluded in writing by parties to resolve a commercial dispute ("settlement agreement") which, at the time of its conclusion, is international in that:

(a) At least two parties to the settlement agreement have their places of business in different States; or

(b) The State in which the parties to the settlement agreement have their places of business is different from either:

(i) The State in which a substantial part of the obligations under the settlement agreement is performed; or

(ii) The State with which the subject matter of the settlement agreement is most closely connected.

2. This Convention does not apply to settlement agreements:

(a) Concluded to resolve a dispute arising from transactions engaged in by one of the parties (a consumer) for personal, family or household purposes;

(b) Relating to family, inheritance or employment lav.

3. This Convention does not apply to:

(a) Settlement agreements:

(i) That have been approved by a court or concluded in the course of proceedings before a court; and

(ii) That are enforceable as a judgment in the State of that court;

(b) Settlement agreements that have been recorded and are enforceable as an arbitral award. 


\section{Article 2. Definitions}

1. For the purposes of article 1, paragraph 1:

(a) If a party has more than one place of business, the relevant place of business is that which has the closest relationship to the dispute resolved by the settlement agreement, having regard to the circumstances known to, or contemplated by, the parties at the time of the conclusion of the settlement agreement;

(b) If a party does not have a place of business, reference is to be made to the party's habitual residence.

2. A settlement agreement is "in writing" if its content is recorded in any form. The requirement that a settlement agreement be in writing is met by an electronic communication if the information contained therein is accessible so as to be useable for subsequent reference.

3. "Mediation" means a process, irrespective of the expression used or the basis upon which the process is carried out, whereby parties attempt to reach an amicable settlement of their dispute with the assistance of a third person or persons ("the mediator") lacking the authority to impose a solution upon the parties to the dispute.

\section{Article 3. Gen eral prin ciples}

1. Each Party to the Convention shall enforce a settlement agreement in accordance with its rules of procedure and under the conditions laid down in this Convention.

2. If a dispute arises concerning a matter that a party claims was already resolved by a settlement agreement, a Party to the Convention shall allow the party to invoke the settlement agreement in accordance with its rules of procedure and under the conditions laid down in this Convention, in order to prove that the matter has already been resolved.

\section{Article 4. Requirements for reliance on settlement agreements}

1. A party relying on a settlement agreement under this Convention shall supply to the competent authority of the Party to the Convention where relief is sought:

(a) The settlement agreement signed by the parties;

(b) Evidence that the settlement agreement resulted from mediation, such as:

(i) The mediator's signature on the settlement agreement;

(ii) A document signed by the mediator indicating that the mediation was carried out;

(iii) An attestation by the institution that administered the mediation; or

(iv) In the absence of (i), (ii) or (iii), any other evidence acceptable to the competent authority.

2. The requirement that a settlement agreement shall be signed by the parties or, where applicable, the mediator is met in relation to an electronic communication if:

(a) A method is used to identify the parties or the mediator and to indicate the parties' or mediator's intention in respect of the information contained in the electronic communication; and

(b) The method used is either:

(i) As reliable as appropriate for the purpose for which the electronic communication was generated or communicated, in the light of all the circumstances, including any relevant agreement; or

(ii) Proven in fact to have fulfilled the functions described in subparagraph (a) above, by itself or together with further evidence. 
3. If the settlement agreement is not in an official language of the Party to the Convention where relief is sought, the competent authority may request a translation thereof into such language.

4. The competent authority may require any necessary document in order to verify that the requirements of the Convention have been complied with.

5. When considering the request for relief, the competent authority shall act expeditiously.

\section{Article 5. Grounds for refusing to grant relief}

1. The competent authority of the Party to the Convention where relief is sought under article 4 may refuse to grant relief at the request of the party against whom the relief is sought only if that party furnishes to the competent authority proof that:

(a) A party to the settlement agreement was under some incapacity;

(b) The settlement agreement sought to be relied upon:

(i) Is null and void, inoperative or incapable of being performed under the law to which the parties have validly subjected it or, failing any indication thereon, under the law deemed applicable by the competent authority of the Party to the Convention where relief is sought under article 4;

(ii) Is not binding, or is not final, according to its terms; or

(iii) Has been subsequently modified;

(c) The obligations in the settlement agreement:

(i) Have been performed; or

(ii) Are not clear or comprehensible;

(d) Granting relief would be contrary to the terms of the settlement agreement;

(e) There was a serious breach by the mediator of standards applicable to the mediator or the mediation without which breach that party would not have entered into the settlement agreement; or

(f) There was a failure by the mediator to disclose to the parties circumstances that raise justifiable doubts as to the mediator's impartiality or independence and such failure to disclose had a material impact or undue influence on a party without which failure that party would not have entered in to the settlement agreement.

2. The competent authority of the Party to the Convention where relief is sought under article 4 may also refuse to grant relief if it finds that:

(a) Granting relief would be contrary to the public policy of that Party; or

(b) The subject matter of the dispute is not capable of settlement by mediation under the law of that Party.

\section{Article 6. Parallel applications or claims}

If an application or a claim relating to a settlement agreement has been made to a court, an arbitral tribunal or any other competent authority which may affect the relief being sought under article 4 , the competent authority of the Party to the Convention where such relief is sought may, if it considers it proper, adjourn the decision and may also, on the request of a party, order the other party to give suitable security.

\section{Article 7. Other laws or treaties}

This Convention shall not deprive any interested party of any right it may have to avail itself of a settlement agreement in the manner and to the extent allowed by 
the law or the treaties of the Party to the Convention where such settlement agreement is sought to be relied upon.

\section{Article 8. Reservations}

1. A Party to the Convention may declare that:

(a) It shall not apply this Convention to settlement agreements to which it is a party, or to which any governmental agencies or any person acting on behalf of a governmental agency is a party, to the extent specified in the declaration;

(b) It shall apply this Convention only to the extent that the parties to the settlement agreement have agreed to the application of the Convention.

2. No reservations are permitted except those expressly authorized in this article.

3. Reservations may be made by a Party to the Convention at any time. Reservations made at the time of signature shall be subject to confirmation upon ratification, acceptance or approval. Such reservations shall take effect simultaneously with the entry into force of this Convention in respect of the Party to the Convention concerned. Reservations made at the time of ratification, acceptance or approval of this Convention or accession thereto, or at the time of making a declaration under article 13 shall take effect simultaneously with the entry into force of this Convention in respect of the Party to the Convention concerned. Reservations deposited after the entry into force of the Convention for that Party to the Convention shall take effect six months after the date of the deposit.

4. Reservations and their confirmations shall be deposited with the depositary.

5. Any Party to the Convention that makes a reservation under this Convention may withdraw it at any time. Such withdrawals are to be deposited with the depositary, and shall take effect six months after deposit.

\section{Article 9. Effect on settlement agreemen ts}

The Convention and any reservation or withdrawal thereof shall apply only to settlement agreements concluded after the date when the Convention, reservation or withdrawal thereof enters into force for the Party to the Convention concerned.

\section{Article 10. Depositary}

The Secretary-General of the United Nations is hereby designated as the depositary of this Convention.

\section{Article 11. Signature, ratification, acceptance, approval, accession}

1. This Convention is open for signature by all States in Singapore, on 1 August 2019, and thereafter at United Nations Headquarters in New York.

2. This Convention is subject to ratification, acceptance or approval by the signatories.

3. This Convention is open for accession by all States that are not signatories as from the date it is open for signature.

4. Instruments of ratification, acceptance, approval or accession are to be deposited with the depositary.

\section{Article 12. Participation by regional economic integration organizations}

1. A regional economic integration organization that is constituted by sovereign States and has competence over certain matters governed by this Convention may similarly sign, ratify, accept, approve or accede to th is Convention. The regional economic integration organization shall in that case have the rights and obligations of a Party to the Convention, to the extent that that organization has competence over 
matters governed by this Convention. Where the number of Parties to the Convention is relevant in this Convention, the regional economic integration organization shall not count as a Party to the Convention in addition to its member States that are Parties to the Convention.

2. The regional economic integration organization shall, at the time of signature, ratification, acceptance, approval or accession, make a declaration to the depositary specifying the matters governed by this Convention in respect of which competence has been transferred to that organization by its member States. The regional economic integration organization shall promptly notify the depositary of any changes to the distribution of competence, including new transfers of competence, specified in the declaration under this paragraph.

3. Any reference to a "Party to the Convention", "Parties to the Convention", a "State" or "States" in this Convention applies equally to a regional economic integration organization where the context so requires.

4. This Convention shall not prevail over conflicting rules of a regional economic integration organization, whether such rules were adopted or entered into force before or after this Convention: (a) if, under article 4, relief is sought in a State that is member of such an organization and all the States relevant under article 1, paragraph 1, are members of such an organization; or (b) as concerns the recognition or enforcement of judgments between member States of such an organization.

\section{Article 13. Non-unified legal systems}

1. If a Party to the Convention has two or more territorial units in which different systems of law are applicable in relation to the matters dealt with in this Convention, it may, at the time of signature, ratification, acceptance, approval or accession, declare that this Convention is to extend to all its territorial units or only to one or more of them, and may amend its declaration by submitting another declaration at any time.

2. These declarations are to be notified to the depositary and are to state expressly the territorial units to which the Convention extends.

3. If a Party to the Convention has two or more territorial units in which different systems of law are applicable in relation to the matters dealt with in this Convention:

(a) Any reference to the law or rule of procedure of a State shall be construed as referring, where appropriate, to the law or rule of procedure in force in the relevant territorial unit;

(b) Any reference to the place of business in a State shall be construed as referring, where appropriate, to the place of business in the relevant territorial unit;

(c) Any reference to the competent authority of the State shall be construed as referring, where appropriate, to the competent authority in the relevant territorial unit.

4. If a Party to the Convention makes no declaration under paragraph 1 of this article, the Convention is to extend to all territorial units of that State.

\section{Article 14. Entry into force}

1. This Convention shall enter into force six months after deposit of the third instrument of ratification, acceptance, approval or accession.

2. When a State ratifies, accepts, approves or accedes to this Convention after the deposit of the third instrument of ratification, acceptance, approval or accession, this Convention shall enter into force in respect of that State six months after the date of the deposit of its instrument of ratification, acceptance, approval or accession. The Convention shall enter into force for a territorial unit to which this Convention has been extended in accordance with article 13 six months after the notification of the declaration referred to in that article. 


\section{Article 15. Amendment}

1. Any Party to the Convention may propose an amendment to the present Convention by submitting it to the Secretary-General of the United Nations. The Secretary-General shall thereupon communicate the proposed amendment to the Parties to the Convention with a request that they indicate whether they favour a conference of Parties to the Convention for the purpose of considering and voting upon the proposal. In the event that within four months from the date of such communication at least one third of the Parties to the Convention favour such a conference, the Secretary-General shall convene the conference under the auspices of the United Nations.

2. The conference of Parties to the Convention shall make every effort to achieve consensus on each amendment. If all efforts at consensus are exhausted and no consensus is reached, the amendment shall, as a last resort, require for its adoption a two-thirds majority vote of the Parties to the Convention present and voting at the conference.

3. An adopted amendment shall be submitted by the depositary to all the Parties to the Convention for ratification, acceptance or approval.

4. An adopted amendment shall enter into force six months after the date of deposit of the third instrument of ratification, acceptance or approval. When an amendment enters into force, it shall be binding on those Parties to the Convention that have expressed consent to be bound by it.

5. When a Party to the Convention ratifies, accepts or approves an amendment following the deposit of the third instrument of ratification, acceptance or approval, the amendment shall enter into force in respect of that Party to the Convention six months after the date of the deposit of its instrument of ratification, acceptance or approval.

\section{Article 16. Denun ciations}

1. A Party to the Convention may denounce this Convention by a formal notification in writing addressed to the depositary. The denunciation may be limited to certain territorial units of a non-unified legal system to which this Convention applies.

2. The denunciation shall take effect 12 months after the notification is received by the depositary. Where a longer period for the denunciation to take effect is specified in the notification, the denunciation shall take effect upon the expiration of such longer period after the notification is received by the depositary. The Convention shall continue to apply to settlement agreements concluded before the denunciation takes effect.

DONE at ... this $[\mathrm{X}]$ day of $[\mathrm{X}] \ldots$..... in a single original, of which the Arabic, Chinese, English, French, Russian and Spanish texts are equally authentic. 